\title{
Manifesto do m. Ç XC celular no bolso
}

Heron Prado

Z6osgzlzhl Âhjluhi . Cf Ffcccc. C

1. a vontade de livrar o peito do peso é importantíssima

1.1 cae já diria que é "importante que alguém esteja curtindo alguma coisa"

1.2 números fracionados são burocráticos

1.3 isso não é um edital

2. jogos podem ser propostos e são apreciados

2.1 o jogo pode ser elaborar um jogo (ou um manifesto)

3. os processos serão avaliados pelo o que foi modificado em seu decorrer e no por seu resultado.

a) os meios são fins e não justificam seus sucessores

b) osso duro de roer, né?

4. é preciso não apenas se absolver dos acidentes processuais como reavaliar sua posição em relação ao erro.

5. olhar para o abismo de vez em quando e não se incomodar com a encarada

5.2 triste seria olhar pro abismo e perder o olhar sem nenhuma resposta

5.3 esquisito seria sentir falta de alguma coisa num lugar desse.

666 submeter todos os seus pensamentos e crenças a uma inversão até não acreditar em nenhum dos dois extremos

7. infelizmente, somos cães, conte com apenas uma vida (que passa rápido)

7.1 apesar de rápida, demora uma vida pra passar

8. o barato é louco e o processo não é apenas lento, é também eterno

(a) $9^{\mathrm{a}}$ arte está nos bytes

9.1 e a vida para lá se dirige

10. eu não queria chegar no dez mas agora já foi

11. há de se fazer. 